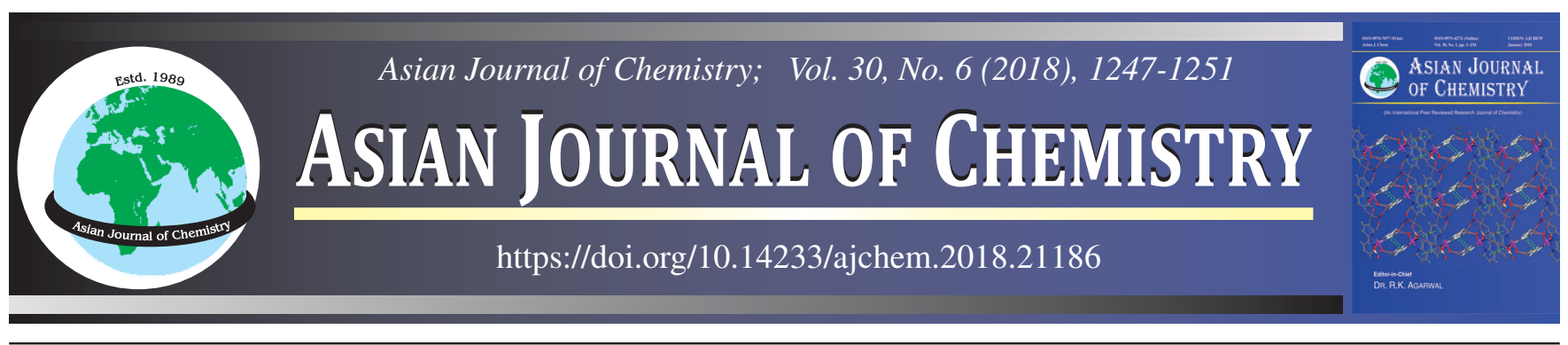

\title{
Electrochemical Reactions of Aldehydes/Ketones at Sacrificial \\ Nickel Anode: Synthesis and Characterization of Nickel(II) Glycolates and Their Coordination Complexes
}

\author{
Shavina, Baljit Singh* and Satinderpal KaUR
}

Department of Chemistry, Punjabi University, Patiala-147 002, India

*Corresponding author: E-mail: baljit_chemz@yahoo.co.in; khanshavina@gmail.com

Received: 15 December 2017;

Accepted: 1 February 2018;

Published online: 30 April 2018;

AJC-18874

\begin{abstract}
Complexes of some aldehydes (acetaldehyde, propionaldehyde, butyraldehyde, cinnamaldehyde and benzaldehyde) and ketones (ethyl methyl ketone, isobutyl methyl ketone, acetophenone, benzophenone and $p$-chlorobenzophenone) have been synthesized at sacrificial nickel anode and inert platinum cathode using tetrabutylammonium chloride as supporting electrolyte. Characterization of compounds by vibrational spectroscopy, elemental analysis and physical measurements confirm that these compounds are unique polymeric nickel(II) glycolates of general formula $\left\{\mathrm{Ni}\left(\mathrm{RR}^{\prime} \mathrm{CO}\right)_{2}\right\}_{\mathrm{n}}$. Refluxing of these glycolates with ligand (2,2'-bipyridyl or 1,10-phenanthroline) does not synthesize coordination compounds. However, the coordination complexes have been synthesized by electrolyzing the aldehyde/ketone in the presence of ligand in acetonitrile at sacrificial nickel anode. Current efficiency of all these systems has been determined in order to check the viability of these reactions on commercial scale.
\end{abstract}

| Keywords: Polymeric nickel(II) glycolate, Sacrificial electrode, Coordination complexes, Current efficiency.

ᄂ - - - - - - - - - - - - - - - - - - - - - - - - - - - - -

\section{INTRODUCTION}

Electrochemical technique is a versatile tool for synthesis in organic [1-3], inorganic [4-7] or organometallic, pharmaceutical $[8,9]$ and nano science $[10,11]$. Electrochemical synthesis has become an accustomed, convenient and environmentally benign alternative to the classical synthetic methods. In electrochemical synthesis: electrodes act as source of or sink for electrons; electrons 'universal chemical reagent' are used for making-breaking of bonds and synthesis takes place at electrode-electrolyte interface. As electrons are used as chemical reagent, therefore traditional oxidation-reduction reactions occur without adding the foreign oxidizing or reducing agents. From the past three decades, variety of metal complexes have been synthesized in our laboratory by direct electrochemical oxidation of various sacrificial anodes [12-19] such as cadmium, mercury, aluminium, zinc, antimony, bismuth, copper. In continuation of our interest in this work, we report the direct electrochemical synthesis and characterization of unique nickel(II) glycolates in this paper. Metal glycolates have several uses such as starting material for fabrication of high dispersion oxide powder [20], microrods [21], microtubes and thin oxide layer deposition [20].

\section{EXPERIMENTAL}

Tetrabutylammonium chloride was purchased from Sigma Aldrich and was used as received without any purification. The solvent acetonitrile was obtained from Merck, dried and purified using molecular sieves of 4A porosity and phosphorus pentoxide and then distilled. All aldehydes/ketones used were commercial products and were used as supplied. Nickel electrode (Sigma Aldrich) of dimensions $0.635 \mathrm{~mm}$ diameter and $5 \mathrm{~cm}$ length was used as sacrificial anode and platinum electrode of dimensions $1 \mathrm{~cm} \times 1 \mathrm{~cm} \times 0.5 \mathrm{~cm}$ was used as inert cathode. H-type glass pyrex cell having two compartments separated by sintered glass disc of G-3 porosity was used as electrolysis vessel. Volume of one compartment is double than the other compartment and were used as anodic and cathodic compartment respectively. Electrolysis was conducted using the electrophoresis power supply of 'Toshniwal' make indicating 0-100 mA current and 0-300 V potential. Stirring of reaction mixture was done using magnetic stirrer of 'Perfit' make and a Teflon sealed magnetic bead. Infrared spectral studies were recorded on 'Elmer FTIR Spectrochem' RXI spectrophotomer using $\mathrm{KBr}$ pallets in the region of $4000-450 \mathrm{~cm}^{-1}$. Carbon, hydrogen and nitrogen contents in metal complexes were deter- 
mined using 'ElementorVario EL' CHNS elemental analyser. Nickel contents were determined volumetrically using oxine [22] method. Melting points of metal complexes were ascertained using electrical device of heating rate $5^{\circ} \mathrm{C}$ per min.

Synthesis of nickel(II) glycolates: Reaction mixture of $3 \mathrm{~mL}$ of aldehyde/ketone and $1.0 \mathrm{~g}$ of tetrabutylammonium chloride in $250 \mathrm{~mL}$ of acetonitrile was prepared and was put into both compartments of H-type cell. Nickel and platinum electrodes were connected to the positive and negative terminals of power supply and were made as sacrificial anode and inert cathode respectively. Electrolytic cell was closed from both openings using guard tubes filled with $\mathrm{CaCl}_{2}$ and glass wool in order to protect the reaction mixture from moisture. Potential across the electrodes was so adjusted that current of $20 \mathrm{~mA}$ passed through the solution. In all cases, hydrogen gas was evolved at cathode.

The electrolytic cell can be summarized as:

$$
\mathrm{Ni}_{(+)}\left|\begin{array}{c}
\mathrm{RR}^{\prime} \mathrm{CO}+\mathrm{CH}_{3} \mathrm{CN} \\
+\mathrm{Bu}_{4} \mathrm{NCl}
\end{array}\right| \mathrm{Pt}_{(-)}
$$

where $\mathrm{Ni}_{(+)}$and $\mathrm{Pt}_{(-)}$are sacrificial nickel anode and inert platinum cathode respectively. RR' CO is aldehyde/ketone ( $\mathrm{R}^{\prime}$ = hydrogen atom, alkyl group for aldehyde and ketone respectively) used as reactant. Tetrabutylammonium chloride $\left(\mathrm{Bu}_{4} \mathrm{NCl}\right)$ used as supporting electrolyte. Acetonitrile used as solvent.

Electrolysis was performed for $8 \mathrm{~h}$ with constant stirring of anodic mixture at constant current of $20 \mathrm{~mA}$. After $5 \mathrm{~min}$, the solution in anodic compartment became sky blue in colour and after $1.0 \mathrm{~h}$, solid compound started depositing on the nickel electrode. After $8 \mathrm{~h}$, the solid compound formed in anodic compartment was filtered, washed with hot acetonitrile and dried with dry diethyl ether in glass filtration unit of G-4 porosity under vacuum. All attempts were made in order to protect the compounds from moisture.

For the synthesis of coordination complexes of nickel(II) glycolates, $1 \mathrm{~g}$ of ligand (2,2'-bipyridyl or 1,10-phenanthroline) was added initially to the above reaction mixture before electrolysis.

The electrolytic cell for the synthesis of coordination compounds is represented as:

$$
\mathrm{Ni}_{(+)}\left|\begin{array}{l}
\mathrm{RR}^{\prime} \mathrm{CO}+\mathrm{CH}_{3} \mathrm{CN} \\
+\mathrm{Bu}_{4} \mathrm{NCl}+\mathrm{L}
\end{array}\right| \mathrm{Pt}_{(-)}
$$

where L: ligand (1,10-phenanthroline or 2,2'-bipyridyl).

\section{RESULTS AND DISCUSSION}

All these metal complexes were not affected much by moisture or air. These compounds were insoluble in mostly used organic solvents like ethanol, acetone, pyridine, benzene, DMSO, DMF, $\mathrm{CS}_{2}, \mathrm{CCl}_{4}$ and $\mathrm{CHCl}_{3}$. All compounds are green in colour except acetaldehyde and cinnamaldehyde system which are greenish cream and light brown respectively. Melting points of all these compounds were determined. The colour change in between $230-250{ }^{\circ} \mathrm{C}$ was seen in all these compounds but these compounds do not have sharp melting points. Colour change in these compounds indicates that these compounds decomposed in this temperature range. These compounds were analyzed for nickel, carbon, hydrogen and nitrogen contents and the results showed agreement in accordance with the expected one. The analytical data showing expected and experimental results is enlisted in Table- 1 and conforms to general formula $\mathrm{Ni}\left(\mathrm{RR}^{\prime} \mathrm{CO}\right)_{2}$.

It has been reported [23-25] that the absorption peaks corresponding to free carbonyl group appear in the region of $1750-1650 \mathrm{~cm}^{-1}$. But in the present compounds, there is no absorption peak in this region which indicates that there is no free carbonyl group present in complexes. However, characteristic absorption bands appeared in the region of 799-459, 1050-942 and 1185-1050 $\mathrm{cm}^{-1}$ (Fig. 1).

It has been reported that the absorption bands corresponding to $v(\mathrm{M}-\mathrm{O})$ [26-32] and $v(\mathrm{C}-\mathrm{O}) \mathrm{M}$ [26-35] stretching vibrations appeared in the region of 800-400 and 1200-950 $\mathrm{cm}^{-1}$, respectively. It has also been reported [24-26] that stretching vibrations due to $\mathrm{v}(\mathrm{C}-\mathrm{O}) \mathrm{M}$ further gets divided into two bands: bands due to bridged alkoxy groups and bands due to terminal alkoxy group. Generally, the bands due to bridged alkoxy group appear at lower frequency than the terminal ones. Respective regions in which absorption bands due to bridged and terminal groups lies are 1050-950 and 1200$1050 \mathrm{~cm}^{-1}$.

So, in the present compounds, the absorption bands in the region of 799-459 $\mathrm{cm}^{-1}$ may be assigned to $\mathrm{v}(\mathrm{Ni}-\mathrm{O})$ stretching vibrations. Moreover, these absorption bands are comparatively broad which indicates that these compounds are polymeric in nature.

It has been reported $[26,28]$ that at inert cathode, radical anion is formed which gets dimerized to form dianion. Under

TABLE-1

ELEMENTAL ANALYSIS AND OTHER RELATED DATA OF ELECTROLYSIS OF

\begin{tabular}{|c|c|c|c|c|c|}
\hline \multirow{2}{*}{ System } & \multirow{2}{*}{ m.f. } & \multicolumn{3}{|c|}{ Elemental analysis (\%): Found (calcd.) } & \multirow{2}{*}{$\begin{array}{l}\text { Current efficiency (gram } \\
\text { equivalent per Faraday) }\end{array}$} \\
\hline & & $\mathrm{C}$ & $\mathrm{H}$ & $\mathrm{Ni}$ & \\
\hline Acetaldehyde & $\mathrm{C}_{4} \mathrm{H}_{8} \mathrm{O}_{2} \mathrm{Ni}$ & $32.5(32.7)$ & $5.2(5.4)$ & $39.7(39.9)$ & 0.69 \\
\hline Propionaldehyde & $\mathrm{C}_{6} \mathrm{H}_{12} \mathrm{O}_{2} \mathrm{Ni}$ & $41.0(41.2)$ & $6.7(6.9)$ & $32.1(33.6)$ & 0.60 \\
\hline Butyraldehyde & $\mathrm{C}_{8} \mathrm{H}_{16} \mathrm{O}_{2} \mathrm{Ni}$ & $47.1(47.4)$ & $7.5(7.9)$ & $28.2(28.9)$ & 0.85 \\
\hline Cinnamaldehyde & $\mathrm{C}_{18} \mathrm{H}_{16} \mathrm{O}_{2} \mathrm{Ni}$ & $66.7(66.9)$ & $4.7(4.9)$ & $17.9(18.2)$ & 0.90 \\
\hline Benzaldehyde & $\mathrm{C}_{14} \mathrm{H}_{12} \mathrm{O}_{2} \mathrm{Ni}$ & $61.7(62.0)$ & $4.3(4.4)$ & $21.2(21.7)$ & 0.71 \\
\hline Ethyl methyl ketone & $\mathrm{C}_{8} \mathrm{H}_{16} \mathrm{O}_{2} \mathrm{Ni}$ & $47.1(47.4)$ & $7.6(7.9)$ & $28.4(28.9)$ & 0.86 \\
\hline Isobutyl methyl ketone & $\mathrm{C}_{12} \mathrm{H}_{24} \mathrm{O}_{2} \mathrm{Ni}$ & $55.5(55.7)$ & $9.1(9.3)$ & $22.6(22.7)$ & 0.60 \\
\hline Benzophenone & $\mathrm{C}_{26} \mathrm{H}_{20} \mathrm{O}_{2} \mathrm{Ni}$ & $73.5(73.7)$ & $4.6(4.7)$ & $13.8(13.9)$ & 0.60 \\
\hline Acetophenone & $\mathrm{C}_{16} \mathrm{H}_{16} \mathrm{O}_{2} \mathrm{Ni}$ & $64.0(64.2)$ & $5.3(5.4)$ & $19.3(19.6)$ & 0.67 \\
\hline p-Chlorobenzophenone & $\mathrm{C}_{26} \mathrm{H}_{18} \mathrm{O}_{2} \mathrm{NiCl}$ & $63.1(63.4)$ & $3.5(3.7)$ & $11.8(11.9)$ & 0.84 \\
\hline
\end{tabular}
ALDEHYDE/KETONE AT SACRIFICIAL NICKEL ANODE 


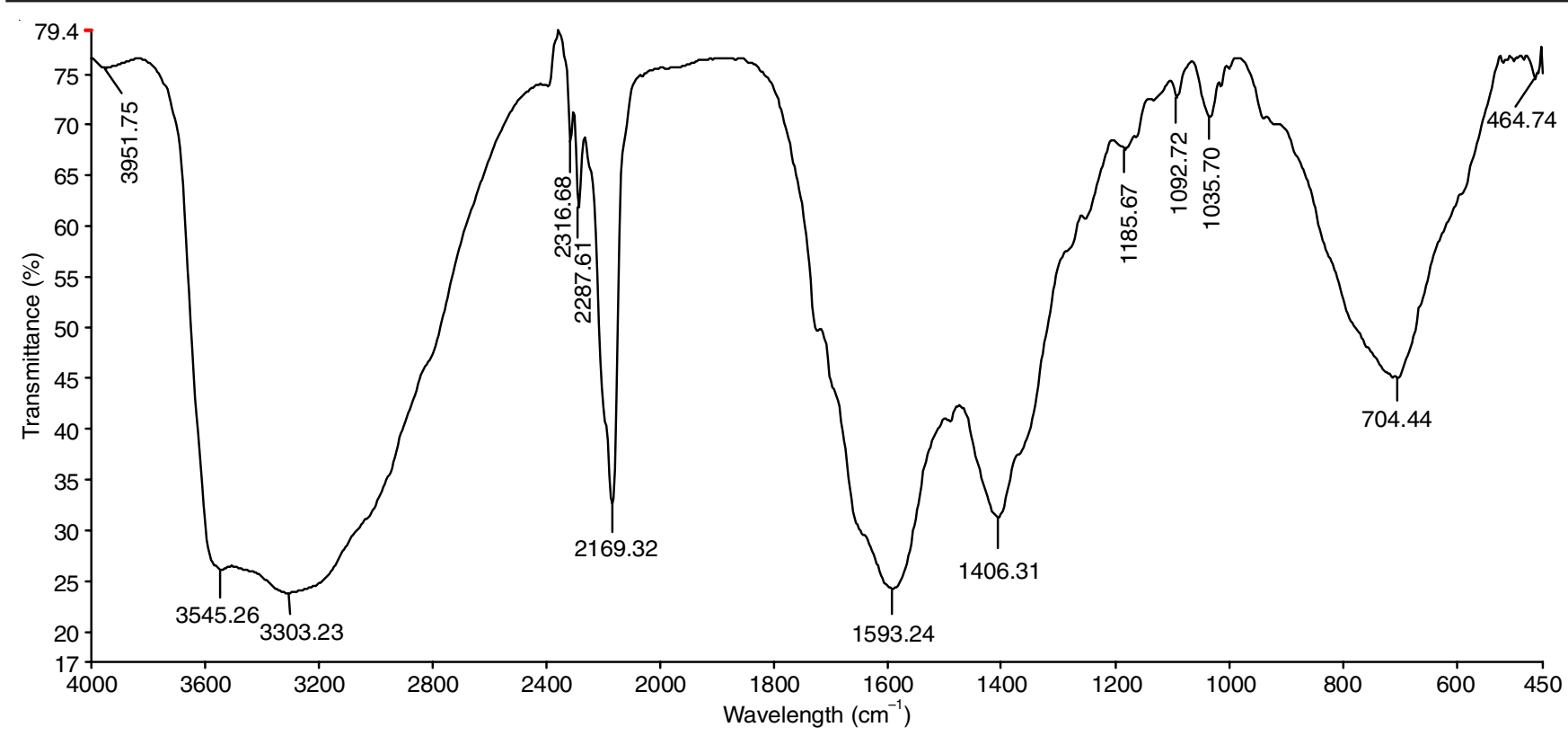

Fig. 1. Infrared spectrum of $\mathrm{Ni}+p$-chlorobenzophenone system

the influence of applied potential, these dianions migrate towards nickel anode and form nickel complexes. As these dianions are similar to glycols, so the resultant compounds formed are known as nickel(II) glycolates. So in these nickel(II) glycolate complexes, the dianion or glycolate moiety serves as a bidentate chelate occupying the coordination sphere of nickel. Therefore, the bands in the region of 1050-942 and $1185-1050 \mathrm{~cm}^{-1}$ may be assigned to $v(\mathrm{C}-\mathrm{O}) \mathrm{Ni}$ bridged and terminal stretching vibrations respectively which corresponds to glycolate moiety linked to nickel. The insoluble nature, high melting points and broad IR peaks confirms that these compounds are unique polymeric nickel(II) glycolates.

The reaction scheme for the synthesis of nickel(II) glycolate is given below:

At inert cathode:<smiles>[R]C(=O)[18F]</smiles><smiles>[R]C([2H])[O-]</smiles><smiles></smiles>

At sacrificial anode:<smiles>[R]C([2H])([2H])C([2H])([2H])[NH2+][C@H]1CC[Nb]O1</smiles>

Coordination complexes of nickel(II) glycolates: An attempt was made in order to synthesize the coordination compounds of these nickel(II) glycolates by refluxing. The parent nickel(II) glycolates were refluxed with ligand (2,2'bipyridyl or 1,10-phenanthroline) in different solvents like acetonitrile, benzene, methanol and ethanol for $48 \mathrm{~h}$. But the analytical and infrared data showed that the ligand molecule could not be attached with the parent nickel(II) glycolates. It may be due to the reason that the nickel metal has already attained the favourable coordination number through bridging; therefore further expansion of coordination sphere by addition of ligand is not possible. Therefore it was thought that if the ligand molecule could be attached before bridging and polymerization, then only the coordination complexes of these nickel(II) glycolates could be formed. This is feasible only by electrochemical synthetic technique. So, these coordination compounds have been synthesized electrochemically by adding $1 \mathrm{~g}$ of ligand to the above substrates before electrolysis and then electrolyzing the reaction mixture for $8 \mathrm{~h}$. After $8 \mathrm{~h}$ electrolysis, the solid product was filtered, washed with hot acetonitrile and dried with dry diethyl ether under vacuum. These compounds showed insoluble nature and high melting points as their parent complexes indicating the polymeric nature. FTIR data of these coordination complexes have exhibited the absorption peaks in the region of 770-454, 1059953, 1198-1059, 1496-1442 and 1609-1518 $\mathrm{cm}^{-1}$ (Fig. 2).

The absorption peaks in the region of 770-454 $\mathrm{cm}^{-1}$ corresponds to $v(\mathrm{Ni}-\mathrm{O})$ stretching vibrations. The absorption peaks in the region of $1059-953 \mathrm{~cm}^{-1}$ and $1198-1059 \mathrm{~cm}^{-1}$ may be assigned to bridged and terminal $v(\mathrm{C}-\mathrm{O}) \mathrm{Ni}$ stretching vibrations. The fascinating feature of these absorption bands is that they have appeared in the higher region $\left(+10-20 \mathrm{~cm}^{-1}\right)$ as compared to the parent compounds. This increase in stretching frequency may be due to the conjugation caused by the ligand molecule. This has been confirmed by the absorption peaks present in the region of 1496-1442 and 1609$1518 \mathrm{~cm}^{-1}$ that may be assigned to $v(\mathrm{C} \cdots \mathrm{\cdots}) / v(\mathrm{C} \cdots \mathrm{\cdots}$-...N) [36-38] ring vibrations of ligand moiety. Also, the peaks were comparatively broad which confirm the polymeric nature of these compounds.

Colour of all compounds of aldehyde/ketone with ligand 1,10-phenanthroline is brown except butyraldehyde and benzaldehyde system which are light green in colour. With ligand 


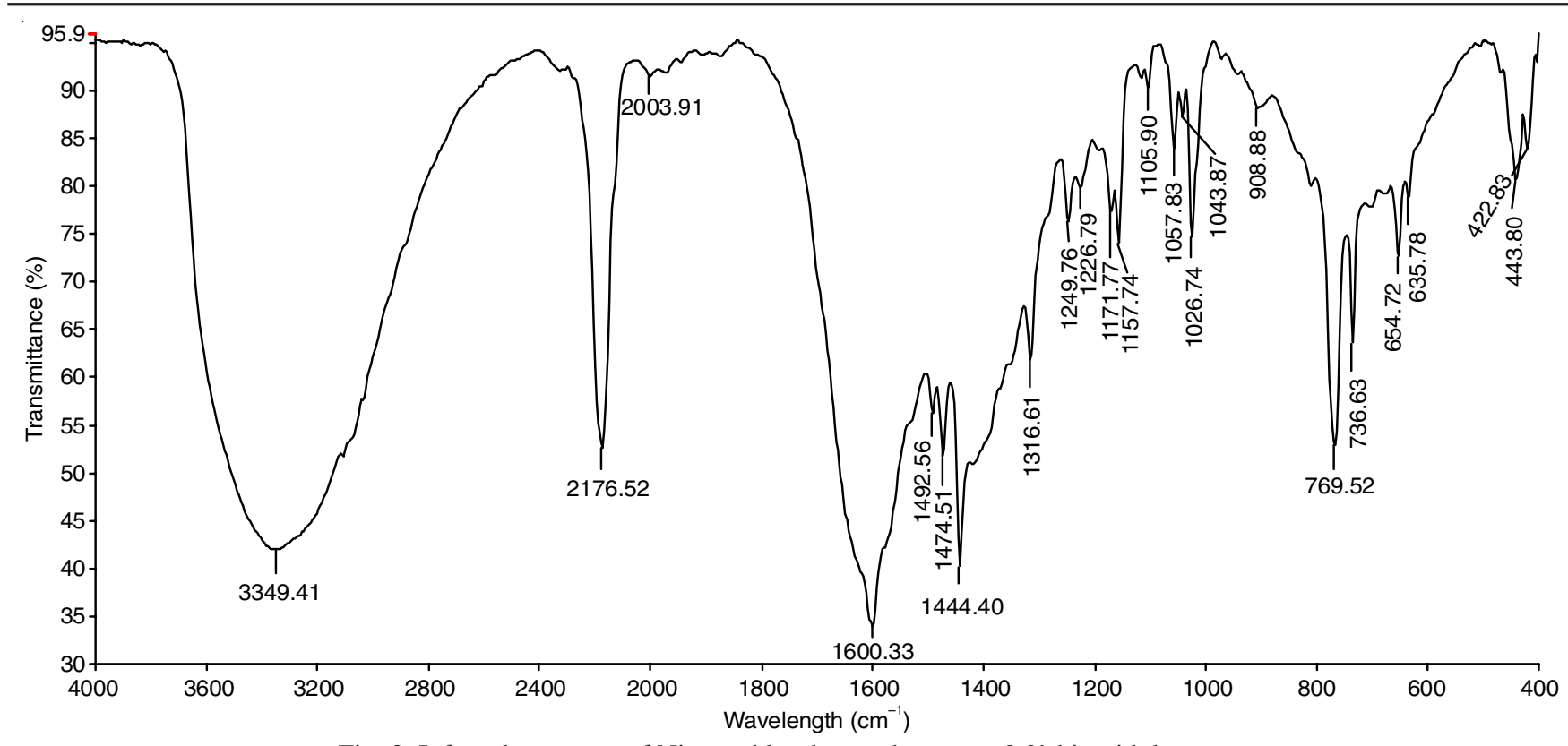

Fig. 2. Infrared spectrum of $\mathrm{Ni}+p$-chlorobenzophenone +2 , 2'-bipyridyl system

2,2'-bipyridyl compounds obtained are of green colour except cinnamaldehyde, ethyl methyl ketone, benzophenone systems which are brown in colour and isobutyl methyl ketone, acetophenone systems which are creamish brown in colour.

Current or electrochemical efficiency: Current efficiency is defined as the gram equivalent of metal dissolved per Faraday of electricity passed. Current efficiency is the ratio of experimental and theoretical amount of nickel dissolved by passing $20 \mathrm{~mA}$ current for exactly $2 \mathrm{~h}$ through the electrolysing solution. Theoretical value of nickel dissolved has been determined using Faraday's first law of electrolysis. The data corresponding to current efficiency values is given in Tables 1 and 2 which shows that these systems have high value of current efficiencies which in turn indicates that the synthesis of nickel(II) glycolates by this method is highly valuable.

\section{Conclusion}

Electrochemical synthesis is highly selective in its ease of operation and uses very mild conditions. Due to potential dependence and temperature independence, this method is highly selective. As the electrons are used as chemical reagents and electric current is used to drive the reaction, this technique is eco-friendly in nature.

\section{ACKNOWLEDGEMENTS}

One of the author (Shavina) is highly thankful to UGC, New Delhi, India for financial assistance.

\begin{tabular}{|c|c|c|c|c|c|c|}
\hline \multicolumn{7}{|c|}{$\begin{array}{c}\text { TABLE-2 } \\
\text { ELEMENTAL ANALYSIS AND OTHER RELATED DATA OF ELECTROLYSIS OF } \\
\text { ALDEHYDE/KETONE + LIGAND SYSTEM AT SACRIFICIAL NICKEL ANODE }\end{array}$} \\
\hline \multirow{2}{*}{ System } & \multirow{2}{*}{ m.f. } & \multicolumn{4}{|c|}{ Elemental analysis (\%): Found (calcd.) } & \multirow{2}{*}{ C.E.* } \\
\hline & & $\mathrm{C}$ & $\mathrm{H}$ & $\mathrm{N}$ & $\mathrm{Ni}$ & \\
\hline Acetaldehyde $+1,10$-phenanthroline & $\mathrm{C}_{16} \mathrm{H}_{16} \mathrm{~N}_{2} \mathrm{O}_{2} \mathrm{Ni}$ & $58.5(58.7)$ & $4.8(4.9)$ & $8.4(8.6)$ & $17.7(17.9)$ & 0.62 \\
\hline Propionaldehyde $+1,10$-phenanthroline & $\mathrm{C}_{18} \mathrm{H}_{20} \mathrm{~N}_{2} \mathrm{O}_{2} \mathrm{Ni}$ & $60.7(60.9)$ & $5.4(5.6)$ & $7.8(7.9)$ & $16.3(16.5)$ & 0.71 \\
\hline Butyraldehyde $+1,10$-phenanthroline & $\mathrm{C}_{20} \mathrm{H}_{24} \mathrm{~N}_{2} \mathrm{O}_{2} \mathrm{Ni}$ & $62.5(62.7)$ & $6.1(6.3)$ & $7.2(7.3)$ & $15.2(15.3)$ & 0.79 \\
\hline Cinnamaldehyde $+1,10$-phenanthroline & $\mathrm{C}_{30} \mathrm{H}_{24} \mathrm{~N}_{2} \mathrm{O}_{2} \mathrm{Ni}$ & $71.5(71.6)$ & $4.6(4.8)$ & $5.5(5.6)$ & $11.5(11.6)$ & 0.82 \\
\hline Benzaldehyde $+1,10$-phenanthroline & $\mathrm{C}_{26} \mathrm{H}_{20} \mathrm{~N}_{2} \mathrm{O}_{2} \mathrm{Ni}$ & $69.0(69.1)$ & $4.3(4.4)$ & $6.0(6.2)$ & $12.8(13.0)$ & 0.68 \\
\hline Ethyl methyl ketone $+1,10$-phenanthroline & $\mathrm{C}_{20} \mathrm{H}_{24} \mathrm{~N}_{2} \mathrm{O}_{2} \mathrm{Ni}$ & $62.5(62.7)$ & $6.1(6.3)$ & $7.0(7.3)$ & $15.3(15.3)$ & 0.98 \\
\hline Isobutyl methyl ketone $+1,10$-phenanthroline & $\mathrm{C}_{24} \mathrm{H}_{32} \mathrm{~N}_{2} \mathrm{O}_{2} \mathrm{Ni}$ & $65.4(65.6)$ & $7.1(7.3)$ & $6.2(6.4)$ & $13.3(13.4)$ & 0.70 \\
\hline Benzophenone $+1,10$-phenanthroline & $\mathrm{C}_{38} \mathrm{H}_{28} \mathrm{~N}_{2} \mathrm{O}_{2} \mathrm{Ni}$ & $4.5(4.6)$ & $75.4(75.6)$ & $4.2(4.6)$ & $9.5(9.7)$ & 0.72 \\
\hline Acetophenone $+1,10$-phenanthroline & $\mathrm{C}_{28} \mathrm{H}_{24} \mathrm{~N}_{2} \mathrm{O}_{2} \mathrm{Ni}$ & $70.0(70.1)$ & $4.8(5.0)$ & $5.6(5.8)$ & $12.2(12.2)$ & 0.68 \\
\hline$p$-Chlorobenzophenone $+1,10$-phenanthroline & $\mathrm{C}_{38} \mathrm{H}_{26} \mathrm{~N}_{2} \mathrm{O}_{2} \mathrm{NiCl}$ & $67.6(67.8)$ & $3.8(3.9)$ & $4.0(4.2)$ & $8.6(8.7)$ & 0.76 \\
\hline Acetaldehyde $+2,2$ '-bipyridyl & $\mathrm{C}_{14} \mathrm{H}_{16} \mathrm{~N}_{2} \mathrm{O}_{2} \mathrm{Ni}$ & $55.2(55.4)$ & $5.1(5.3)$ & $9.0(9.2)$ & $19.3(19.4)$ & 0.71 \\
\hline Propionaldehyde $+2,2^{\prime}$-bipyridyl & $\mathrm{C}_{16} \mathrm{H}_{20} \mathrm{~N}_{2} \mathrm{O}_{2} \mathrm{Ni}$ & $57.8(58.0)$ & $5.8(6.0)$ & $8.3(8.5)$ & $17.5(17.7)$ & 0.75 \\
\hline Butyraldehyde $+2,2$ '-bipyridyl & $\mathrm{C}_{18} \mathrm{H}_{24} \mathrm{~N}_{2} \mathrm{O}_{2} \mathrm{Ni}$ & $60.0(60.2)$ & $6.5(6.7)$ & $7.6(7.8)$ & $16.3(16.4)$ & 0.83 \\
\hline Cinnamaldehyde $+2,2$ '-bipyridyl & $\mathrm{C}_{28} \mathrm{H}_{24} \mathrm{~N}_{2} \mathrm{O}_{2} \mathrm{Ni}$ & $70.0(70.1)$ & $4.8(5.0)$ & $5.6(5.8)$ & $12.1(12.2)$ & 0.89 \\
\hline Benzaldehyde $+2,2$ '-bipyridyl & $\mathrm{C}_{24} \mathrm{H}_{20} \mathrm{~N}_{2} \mathrm{O}_{2} \mathrm{Ni}$ & $67.2(67.4)$ & $4.6(4.7)$ & $6.5(6.6)$ & 13.5 (13.7) & 0.84 \\
\hline Ethyl methyl ketone $+2,2$ '-bipyridyl & $\mathrm{C}_{18} \mathrm{H}_{24} \mathrm{~N}_{2} \mathrm{O}_{2} \mathrm{Ni}$ & $60.0(60.2)$ & $6.6(6.7)$ & $7.6(7.8)$ & $16.1(16.4)$ & 0.87 \\
\hline Isobutyl methyl ketone $+2,2$ '-bipyridyl & $\mathrm{C}_{22} \mathrm{H}_{32} \mathrm{~N}_{2} \mathrm{O}_{2} \mathrm{Ni}$ & $63.5(63.6)$ & $7.5(7.7)$ & $6.5(6.7)$ & $14.0(14.1)$ & 0.72 \\
\hline Benzophenone $+2,2$ '-bipyridyl & $\mathrm{C}_{36} \mathrm{H}_{28} \mathrm{~N}_{2} \mathrm{O}_{2} \mathrm{Ni}$ & $74.4(74.6)$ & $4.7(4.8)$ & $4.6(4.8)$ & $9.9(10.1)$ & 0.69 \\
\hline Acetophenone $+2,2$ '-bipyridyl & $\mathrm{C}_{26} \mathrm{H}_{24} \mathrm{~N}_{2} \mathrm{O}_{2} \mathrm{Ni}$ & $68.3(68.5)$ & $5.1(5.3)$ & $6.0(6.2)$ & $12.4(12.9)$ & 0.70 \\
\hline$p$-Chlorobenzophenone $+2,2$-bipyridyl & $\mathrm{C}_{36} \mathrm{H}_{26} \mathrm{~N}_{2} \mathrm{O}_{2} \mathrm{NiCl}$ & $66.5(66.6)$ & $3.8(4.0)$ & $4.1(4.3)$ & $9.0(9.1)$ & 0.80 \\
\hline
\end{tabular}




\section{REFERENCES}

1. E.J. Horn, B.R. Rosen and P.S. Baran, ACS Cent. Sci., 2, 302 (2016); https://doi.org/10.1021/acscentsci.6b00091.

2. J.E. Dick and D. Chong, Org. Chem. Curr. Res., 1, e113 (2012); https://doi.org/10.4172/2161-0401.1000e113.

3. B.A. Frontana-Uribe, R.D. Little, J.G. Ibanez, A. Palma and R. VasquezMedrano, Green Chem., 12, 2099 (2010); https://doi.org/10.1039/c0gc00382d.

4. A.M. Vecchio-Sadus, J. Appl. Electrochem., 23, 401 (1993); https://doi.org/10.1007/BF00707616.

5. A.D. Garnovskii, L.M. Blanco, B.I. Kharisov, D.A. Garnovskii and A.S. Burlov, J. Coord. Chem., 48, 219 (1999); https://doi.org/10.1080/00958979908024555.

6. G.H.A. Therese and P.V. Kamath, Chem. Mater, 12, 1195 (2000); https://doi.org/10.1021/cm990447a.

7. S.R. Long and J.J. Lagowski, Synth. React. Inorg. Met.-Org. Nano-Met. Chem., 37, 813 (2007); https://doi.org/10.1080/15533170701748548.

8. A.P. Tomilov and I.N. Chernykh, Pharm. Chem. J., 28, 573 (1994); https://doi.org/10.1007/BF02219034.

9. S. Torres, R. Brown, R. Szucs, J.M. Hawkins, G. Scrivens, A. Pettman, D. Kraus and M.R. Taylor, Org. Process Res. Dev., 19, 1596 (2015); https://doi.org/10.1021/op500312e.

10. I.A. Novoselova, S.V. Kuleshov, S.V. Volkov and V.N. Bykov, Electrochim. Acta, 211, 343 (2016); https://doi.org/10.1016/j.electacta.2016.05.160.

11. R.A. Khaydarov, R.R. Khaydarov, O. Gapurova, Y. Estrin and T. Scheper, J. Nanopart. Res., 11, 1193 (2009); https://doi.org/10.1007/s11051-008-9513-x.

12. J.S. Banait, S.K. Deol and B. Singh, Synth. React. Inorg. Met.-Org. Chem., 20, 1331 (1990); https://doi.org/10.1080/00945719008048637.

13. J.S. Banait and B. Singh, Indian J. Chem., 30A, 895 (1991).

14. J.S. Banait, B. Lal and B. Singh, J. Electrochem Soc., 41, 23 (1992),

15. J.S. Banait and B. Singh, J. Electrochem Soc., 45, 103 (1996).

16. J.S. Banait, B. Singh and H. Kaur, Indian J. Chem., 46A, 266 (2007).

17. J.S. Banait, B. Singh and S. Rala, J. Indian Chem. Soc., 84, 25 (2007).

18. B. Singh and H. Kaur, J. Indian Chem. Soc., 85, 849 (2008).

19. B. Singh, Shavina and K. Bala, Chem. Sci. Rev. Lett., 3, 367 (2014).

20. E.E. Grinberg, I.E. Strelnikova, A.E. Amelina and Y.I. Levin, Inorg. Mater: Appl. Res., 8, 21 (2017); https://doi.org/10.1134/S2075113317010166.
21. F. Tao, M. Guan, Y. Zhou, L. Zhang, Z. Xu and J. Chen, Cryst. Growth Des., 8, 2157 (2008); https://doi.org/10.1021/cg7012123.

22. A.I. Vogel, Text book of Quantitative Chemical Analysis, Longman group UK Ltd., edn 5 (1989).

23. J.R. Dyer's, Applications of Absorption Spectroscopy of Organic Compound, Prentice-Hall of India Pvt. Ltd., New Delhi (1969).

24. A.A. Olanrewaju, T.I. Oni and A.A. Osowole, Chem. Res. J., 1, 90 (2016).

25. M.V. Chaud, A.C. Lima, M.M.D.C. Vila, M.O. Paganelli, F.C. Paula, L.N. Pedreiro and M.P.D. Gremião, Trop. J. Pharm. Res., 12, 163 (2013); https://doi.org/10.4314/tjpr.v12i2.5.

26. J.S. Banait, N. Arora and B. Singh, J. Electrochem Soc., 49, 10 (2000).

27. J.S. Banait, B. Singh and H. Kaur, J. Indian Chem. Soc., 88, 641 (2011).

28. K. Bala and B. Singh, World J. Pharm. Pharm. Sci., 5, 1864 (2016).

29. N.B. Sharma, J. Shahai, R.S. Ghadwal, A. Singh, E. Jeanneau and S. Mishra, J. Coord. Chem., 69, 135 (2016);

https://doi.org/10.1080/00958972.2015.1112900.

30. K. Takasea, H. Nishizawa, A. Onda, K. Yanagisawa and S. Yin, J. Asian Ceramic Soc., 5, 482 (2017); https://doi.org/10.1016/j.jascer.2017.10.007.

31. M. Sharma, A. Singh and R.C. Mehrotra, Indian J. Chem., 38A, 1209 (1999).

32. N. Phonthammachai, T. Chairassameewong, E. Gulari, A.M. Jamieson and S. Wongkasemjit, J. Metals Mater. Minerals (Chulalongkorn Univ.), 12, 23 (2002).

33. D.C. Bradley and A.H. Westlake, Proceedings of Symposium in Coordination Chemistry, Hungarian Academy of Science, Budapest, p. 309 (1965).

34. G.A. Kakos and G. Winter, Aust. J. Chem., 20, 2343 (1967); https://doi.org/10.1071/CH9672343.

35. C.H. Brubaker Jr. and M. Wicholas, J. Inorg. Nucl. Chem., 27, 59 (1965); https://doi.org/10.1016/0022-1902(65)80190-7.

36. A.J. Pallenberg, K.S. Koenig and D.M. Barnhart, Inorg. Chem., 34, 2833 (1995); https://doi.org/10.1021/ic00115a009.

37. S. Tosonian, C. J. Ruiz, A. Rios, E. Frias and J.F. Eichler, Open J. Inorg. Chem., 3, 7 (2013); https://doi.org/10.4236/ojic.2013.31002.

38. P.L. Bellavance, E.R. Corey, J.Y. Corey and G.W. Hey, Inorg. Chem., 16, 462 (1977); https://doi.org/10.1021/ic50168a048. 